\title{
Infrastructural Resources Managerial Practices of Principals for the Implementation of Entrepreneurship Studies in Public and Private Secondary School in Anambra State
}

\author{
Emegwa Tina Uzoamaka \\ Department of Educational Management and Policy, \\ Nnamdi Azikiwe University, Awka, Anambra State, Nigeria
}

\begin{abstract}
The purpose of this study was to investigate principals' infrastructural resources managerial practices for the implementation of entrepreneurship studies in public and private secondary school in Anambra State. One research question and one null hypothesis guided the study. The descriptive survey research design was adopted for this study which was conducted in public and private secondary school in Anambra State. The population for this study is $\mathbf{1 6 , 7 2 7}$ respondents while the sample size for this study is $\mathbf{1 , 3 3 2}$ respondents drawn from public and private secondary schools in Anambra state using simple random sampling technique balloting with replacement. A researcher-developed instrument was the instrument for data collection. The validity and reliability of the instrument were determined. The Cronbach reliability co-efficient of 0.82 was obtained for the instrument. The researcher assisted by six research assistants who are teachers in the state administered the instrument. Mean scores were used to answer the research question while $t$ - test was used to test the hypothesis at 0.05 level of significance. Findings indicated that principals and teachers in public and private secondary schools do not differ significantly in their mean ratings on infrastructural resources managerial practices for the implementation of entrepreneurship studies in Anambra State. It was among others recommended that principals in public and private secondary schools in Anambra state should ensure that current books on entrepreneurship are provided in the school library.
\end{abstract}

Keywords:- Infrastructure; Infrastructural Resource; Managerial Practice; Principal; Implementation; Entrepreneurship Study.

\section{INTRODUCTION}

Nigeria, like other countries of the world, acknowledges the fact that education is a vital tool for achieving national development. The Federal Government of Nigeria in its National Policy on Education (2013), considered education as bedrock of any meaningful development, be it social, economic or political. Consequently, Nigeria has joined other nations of the world in the match towards worthwhile educational investments and reforms especially in the provision of formal education.
Formal education in the country is organized in three levels which include Basic, Secondary and Tertiary. The purpose of each level of formal education is to effect positive changes in children's behaviour by exposing them to relevant experiences through systematic presentation of skills, attitudes, concepts and principles (Ida, 2016).

Secondary school education is the form of education children receive after the basic education and before the tertiary stage. Its importance lies in its position both as the bridge between the basic and tertiary education and the agent for preparing individuals for useful living in the society, Federal Republic of Nigeria (FRN, 2013). In line with one of the objectives of secondary education which according to FRN (2013) is to provide entrepreneurial, technical and vocational job specific skills for self-reliance and for agricultural, industrial, commercial and economic development, secondary school students upon graduation should have been exposed to various entrepreneurship skills such as upholstery, carpentry and joinery, garment making, painting, clothing and textile among others. This exposure is to enhance their ability to use such skills to find lasting solution to life needs.

Entrepreneurship study is a specialized training given to persons to acquire skills, ideas and management abilities necessary for self reliance. In Nigeria, the level of awareness of entrepreneurship seems to be very low. This is attributable to low entrepreneurship study which is one of the major factors leading to unemployment in country. Olodi (2000) and Agwaga (2000) remarked that the absence of a functional entrepreneurship curriculum is an impediment to sustainable development which if not checked or tackled will continue to incite and increase the incidence of unemployment among Nigerian populace. It is therefore necessary to establish entrepreneurship in secondary education which will help teachers to start on time to identify entrepreneurial characteristics in the school children from primary to secondary school in other to catch them young and encourage them accordingly. In the classroom, the teacher is the manager of learning process. According to Obanya (2007), teachers should be well groomed in their specialized areas, highly organized, energetic, self-motivated, have interpersonal skills, have capacity to cope with pressure posed excellent strategic thinking ability and ready to take challenges and work to 
deadlines. Obanya further opined that the solution to unemployment is not increased vocalization of education as wrongly being canvassed, but a return to the basics. This means returning to real goals of education, which is the cultivation of human talent and creative and imaginative potentials through all round development. This calls for effective integration of entrepreneurship education in the school programme.

Furthermore, Halfdan (2002) outlined the current trend used in integrating entrepreneurship education in schools. He mentioned that learners are presented to self employment career option through the compulsory "guidance and counselling awareness development". This is an important strategy that can also be used to motivate potential entrepreneurs in secondary schools. Halfdan further noted that involving the students in entrepreneurship studies will motivate them into planning and how to start and run a business of their own. He further defined entrepreneurship studies as the teaching of knowledge and skills that will enable the students to plan, start and run a business.

Again, Usman (2017) observed that counsellors provide training innovative skills and knowledge to students which will enable them to cope in life. Anyamene, Anyachebelu and Izuchi (2010: p.179) stated some strategies used by the counsellors in promoting entrepreneurship to include:

$>$ Organizing seminars and workshops for students.

$>$ Assisting students to understand and channel their talents.

$>$ Helping them to develop positive attitude and self confidence in understanding self employment ventures.

$>$ Motivating students to undertake entrepreneurship education.

$>$ Promoting self evaluation in students.

$>$ Counselling the students to understand area of interest.

Counselling students to take active part in the learning of entrepreneurship can only be effective if infrastructural resources are properly managed. The management of infrastructural resources begins with the provisions of the resources. This is a crucial role which the school principal performs. Infrastructural management deals with the school plant and surrounding physical environment with the aim of making them conducive for learning. The principal's role here is to procure and organize these facilities effectively with the help of relevant staff in order to achieve the organizational goals. According to Achilike (2016:10), "effective managerial leadership is the key to establishing a climate conductive to academic learning and achievement". Hence, school principals should create a school environment where academic achievement should be the primary goal to be realized by the school. Again, Ejiogu (2002) had earlier observed that the major responsibilities in this regard call for adequate care of plants and facilities, involving the entire school personnel in their maintenance. This means that the principal should devise supervisory schedules to avoid neglecting the plants and facilities; procure adequate quantity and quality of the school personnel to enable the plants and facilities function at the optimum capacities and crate awareness among the staff regarding the importance of well-kept school plants and facilities.

Several studies have been carried out on entrepreneurship. For example, Adeyonu and Carim-Sanni, (2015) carried out a study on the assessment of the new trade/Entrepreneurship education in senior secondary education: Case study of rural and urban secondary schools in of Oyo State, Nigeria. The study found among others that students have learnt two subjects out of 10 entrepreneurship subjects in rural areas and six out of 11 entrepreneurship subjects in urban areas.

Again, Onyebu (2015) carried out a study on the role of acquiring entrepreneurship skill in for academic performance: a case study of selected universities in Abia State Nigeria. The study found among others that significant relationship exist between entrepreneurship skills and academic performance of students. Achilike (2016) also carried out a study on the competency improvement needs of head teachers of primary schools in supervision of instruction in Anambra State. The researchers found that supervision enhance quality instruction. The researchers recommended capacity building programmes on supervision of instruction for teachers. Infrastructural facilities or resources are also part of the things being supervised in schools.

The reason for this is very obvious. The Anambra state government, through the Ministry of Education, has provided many infrastructural resources in secondary schools in the state. Personal experience of the researcher indicated that virtually, all the secondary schools in Anambra state have new classroom blocks; new office blocks and libraries and laboratories stocked with new acquisitions. The problem is that those facilities are either underutilized or not utilized at all. Most of them are under lock and key. The above situation raises a big question as to the reason for their provision.

\section{* Purpose of the Study}

The purpose of this study was to investigate principals' infrastructural resources managerial practices for the implementation of entrepreneurship studies in public and private secondary school in Anambra State.

Research Question: What are the infrastructural resources managerial practices of principals for the implementation of entrepreneurship studies in public and private secondary school in Anambra State?

Null Hypothesis: Principals and teachers in public and private secondary schools do not differ significantly in their mean ratings on how they manage infrastructural resources for the implementation of entrepreneurship studies in Anambra State. 


\section{* Research Design}

The descriptive survey research design was adopted for this study which was conducted in public and private secondary school in Anambra State. All the Education zones in the state namely Aguata, Awka, Nnewi, Ogidi, Onitsha, Otuocha were used. The population for this study is 16,727 respondents which is made up of 481 principals and 9,697 teachers in the 481 private secondary schools and 256 principals and 6,293 teachers in the 256 public secondary schools in Anambra state. The sample size for this study is 1,332 respondents drawn from public and private secondary schools in Anambra state using simple random sampling technique balloting with replacement.
Researcher-developed instrument was the instrument for data collection. The validity of the instrument was determined using three lecturers: one in Educational Management and Policy; one in Measurement and Evaluation and one lecturer in Vocational Education, all in Faculty of Education, Nnamdi Azikiwe University, Awka. The reliability of the questionnaire was determined by administering copies of the questionnaire to 45 respondents made up of 15 principals and 30 teachers in Enugu State. The Cronbach reliability co-efficient of 0.82 was obtained for the instrument. The researcher assisted by six research assistants who are teachers in the state administered the instruments directly to the respondents. Mean scores were used to answer the research question while t- test was used to test the hypothesis at 0.05 level of significance.

\section{PRESENTATION OF RESULTS}

Research Question: What are the infrastructural resources managerial practices of principals for the implementation of entrepreneurship studies in public and private secondary school in Anambra State?

\begin{tabular}{|c|c|c|c|c|c|c|c|}
\hline & $\begin{array}{c}\text { Principals' Infrastructural Managerial } \\
\text { Practices for Implementing Entrepreneurship } \\
\text { Studies }\end{array}$ & \multicolumn{2}{|c|}{$\begin{array}{c}\text { Public School } \\
\text { (N = 466) }\end{array}$} & \multicolumn{2}{c|}{$\begin{array}{c}\text { Private School } \\
\text { (N = 861) }\end{array}$} \\
\hline S/N & Items & Mean & SD & Remark & Mean & SD & Remark \\
\hline 1 & $\begin{array}{c}\text { Liaising with the PTA to ensure that } \\
\text { entrepreneurship teaching materials are provided } \\
\text { for students. }\end{array}$ & 2.63 & .81 & Agree & 3.17 & .64 & Agree \\
\hline 2 & $\begin{array}{c}\text { Soliciting private sector participation in } \\
\text { providing entrepreneurship teaching facilities } \\
\text { for the students. }\end{array}$ & 2.44 & .86 & Disagree & 3.14 & .72 & Agree \\
\hline 3 & $\begin{array}{c}\text { Ensuring regular maintenance of } \\
\text { entrepreneurship practical workshop by } \\
\text { repairing broken windows, leaking roofs, and } \\
\text { holes in floors including equipment for learning. }\end{array}$ & 2.51 & .85 & Agree & 3.15 & .72 & Agree \\
\hline 4 & $\begin{array}{c}\text { Ensuring that flowers are planted in and around } \\
\text { the entrepreneurship workshop. }\end{array}$ & 2.41 & .85 & Disagree & 3.20 & .73 & Agree \\
\hline 5 & $\begin{array}{c}\text { Providing generating sets for electricity in the } \\
\text { entrepreneurship workshop when there is power } \\
\text { failure. }\end{array}$ & 2.35 & .72 & Disagree & 3.22 & .70 & Agree \\
\hline 6 & $\begin{array}{c}\text { Ensuring that current books on entrepreneurship } \\
\text { are provided in the school library. }\end{array}$ & 2.42 & .74 & Disagree & 2.44 & .87 & Disagree \\
\hline 7 & $\begin{array}{c}\text { Ensuring that classrooms are adequate in } \\
\text { number for effective implementation of } \\
\text { entrepreneurship studies in the school. }\end{array}$ & 2.62 & .73 & Agree & 2.86 & .75 & Agree \\
\hline 8 & $\begin{array}{c}\text { Mobilizing parents to provide entrepreneurship } \\
\text { teaching facilities to the school. }\end{array}$ & 2.34 & .67 & Disagree & 3.18 & .76 & Agree \\
\hline & Mean of Means & $\mathbf{2 . 4 6}$ & $\mathbf{0 . 7 7}$ & Disagree & $\mathbf{3 . 0 5}$ & $\mathbf{. 0 7 3}$ & Agree \\
\hline
\end{tabular}

Table 1:- Mean Ratings on Principals’ Infrastructural Managerial Practices for Implementing Entrepreneurship Studies

The results in table 1 show that the mean of means for public schools on infrastructural managerial practices is 2.46 indicating disagreement on the infrastructural resources for the implementation of entrepreneurship studies. On the other hand, the mean of means for private secondary schools on the infrastructural managerial practices is 3.05 indicating agreement on the infrastructural managerial resources for the implementation of entrepreneurship studies in the state.
The item by item analysis shows that item 1to 8 have mean ratings ranging from 2.34 to 2.62 for public schools and mean ratings ranging from 2.44 to 3.22 for private schools. In public secondary schools, items 1 and 7 have the highest mean rating of 2.63 and 2.62 respectively indicating that principals in public schools liaise with the P.T.A. to ensure that entrepreneurship teaching materials are provided for students and, as well ensure that classrooms are adequate in number for effective implementation of entrepreneurship studies in the schools. 
Similarly, in private schools, item 5 has the highest mean rating of 3.22 indicating that principals in private schools provide generating sets for electricity in entrepreneurship workshop when there is power failure in their schools.

On the other hand, items 8 has the lowest mean rating of 2.34 for public schools and thus indicates that principals in public secondary schools do not mobilize parents to provide entrepreneurship teaching facilities to the schools. In the same manner, item 6 has the lowest mean rating of 2.44 for private secondary schools indicating that principals in private secondary schools in Anambra State do not ensure that current books on entrepreneurship are provided in their school library. The standard deviation has the mean of 0.77 for public schools while the private schools has the S.d. mean of 0.73 . The standard deviations clustered around the means. They did not deviate much from the means.

Hypothesis: Principals and teachers in public and private secondary schools do not differ significantly in their mean ratings on infrastructural resources managerial practices for the implementation of entrepreneurship studies in Anambra State.

\begin{tabular}{|c|c|c|c|c|c|c|c|}
\hline $\begin{array}{l}\text { Source of } \\
\text { Variation }\end{array}$ & & & & & & & \\
\hline & $\mathbf{N}$ & Mean & SD & z-cal & Df & z-crit & Decision \\
\hline Public School & 465 & 2.46 & 0.77 & & & & \\
\hline & & & & 1.86 & 1325 & 1.96 & Significant \\
\hline Private School & 862 & 3.05 & 0.73 & & & & \\
\hline
\end{tabular}

Table 2:- t-test of Principals and teachers' mean responses on infrastructural resources managerial practices for the implementation of entrepreneurship studies in Anambra State

The t-test analysis in table 2 shows that the t-cal value of 1.86 was less critical value t-value of 1.96 at alpha level of 0.05 and degree of freedom (df) 1325. This is an indication that the difference in the mean responses of principals and teachers responses on infrastructural resources managerial practices for the implementation of entrepreneurship studies in Anambra State was not significant. Therefore, the null hypothesis was not significant.

\section{$>$ Summary of Findings}

Base on the data presentation and analysis, the following findings were made:

- Public secondary school principals mobilize PTA and parents to ensure that infrastructural facilities are provided for the teaching of entrepreneurship studies but private secondary schools do not.

- Private secondary school principals unlike those in public secondary schools provide generating sets for electricity in their entrepreneurship workshop when there is power failure.

- Principals and teachers in public and private secondary schools do not differ significantly in their mean ratings on infrastructural resources managerial practices for the implementation of entrepreneurship studies in Anambra State.

\section{$>$ Discussion of Findings}

The analysis of data for the research question revealed that public secondary school principals, unlike their private school counterparts, mobilize PTA and parents to ensure that infrastructural facilities are provided for the teaching of entrepreneurship studies. Further findings indicate that private secondary school principals provide generating set for the teaching of entrepreneurship subjects when there is electricity failure in the schools. Data analysis for the hypothesis revealed that principals and teachers in public and private secondary schools do not differ significantly in their mean ratings on infrastructural resources managerial practices for the implementation of entrepreneurship studies in Anambra State.

The above findings were supported by Babalola (2006) who found that public secondary school principals adequately motivated parents to provide entrepreneurship teaching facilities in public schools. This is true because, in some schools especially in rural areas, parents do provide teaching facilities. Some community schools also were built by the communities and handed over to the government. In such schools, parents, through PTAs, normally ensure that teaching facilities do not lack in them. It is therefore little wonder if parents provide entrepreneurship teaching facilities in public secondary schools. In support of the above findings too, Allison (2001) found that there is no significant difference in the mean ratings of public and private secondary school principals on their infrastructural resource managerial facilities. The agreement among the studies could be attributed to the designs and respondents used. The studies used the same design and respondents.

\section{CONCLUSION}

From the interpretation of data and discussion of the findings of this study, the conclusion in this study is infrastructural resources must be effectively and efficiently handle for the overall success of entrepreneurship studies. It is also concluded in this study that certain infrastructural resources managerial practices are not efficiently practiced in either or both public and private secondary schools in Anambra State. 


\section{RECOMMENDATIONS}

Based on the results of this research, the following recommendations were made:

$>$ Public secondary schools principals in Anambra State should nurture co-operative work environment among entrepreneurship teachers in their schools for effective and efficient use of infrastructural resources.

Since text selection is important in teaching and learning activities, public schools should involve their teachers in selecting good entrepreneurship texts for their students.

$>$ Principals in public and private secondary schools in Anambra state should ensure that current books on entrepreneurship are provided in the school library.

\section{REFERENCES}

[1]. Achilike, A. (2016). The key to effective resource management: a look at the overlooked. Interdisciplinary Education Journal. 4(2) 4-46.

[2]. Adeyonu, A.G. \&Carim - Sanni, A. (2015).Assessment of the new entrepreneurship Education in senior secondary schools. A case study of rural and urban secondary school in Oyo state.Retrieved on $2^{\text {nd }}$ October, 2017 from http://dc.etsu.edu/etd/2015.

[3]. Agwagah, U.N.O (2000). Sustainability of poverty alleviation institute in Nigeria. Business Education Journal, 1(6), 40-47.

[4]. Allison, M.A. (2001). The head teachers' role in school effectiveness. Dordrecht: Kluwer Academic publishers.

[5]. Anekwe, R.E. (2004). The influence of internal and external supervision on teacher effectiveness. Unpublished M.Ed. Thesis, Nnadmi Azikiwe University Awka.

[6]. Anyamene, F. C. Anyachebulu O.J. \& Izuchi, N.C. (2010) strategies for promoting entrepreneurship Education among under graduates: the perception of counsellers. Orient Journal of Education, 5 (2), 176190.

[7]. Babalola, J.B. (2006). Strategic management of secondary education in Nigeria. Lead paper presented at a conference in strategic

[8]. Ejiogu, A. (2002, April). Professionalism and public participation in education policy-making. Paper Presented at the Annual Meeting of the America Educational Research Association, Boston, April.

[9]. Federal Republic of Nigeria (FRN, 2013).National policy on Education. Lagos: NERDC press.

[10]. Halfdan .F. (2002). Integrating entrepreneurship education in Bostwana, Uganda and Kenya Norway: National institute of technology.

[11]. Ida, D.J. (2016). Secondary School headship in the Nigerian context.Nsukka : University publishing co management in the education sector organized by the Nigerian Educational Research and Development Council at Abuja in February 2006.
[12]. Obanya, P. (2007). Dreaming, leaving and doing education Ibadan: Educational research and study group 2(3) 5-12.

[13]. Olodi, F.J. (2000). The economic history of poverty alleviation in Nigeria. Journal of the Nigeria research association 14(2) 17-22.

[14]. Onyegbu, L.O. (2015). The role of acquiring entrepreneurship skills for academic performance, A case study of selected Universities in Abia State, Nigeria. Higher Education in focus.A journal of Educational Review 3 (2) 151-179.

[15]. Usman, M. (2017). A counseling guide for students, Ibadan: University press. 